\title{
Design, Synthesis and Cancer Cell Line Activities of Pyrazolo[3,4-b]pyridine Derivatives
}

\author{
Mosaad Sayed Mohamed ${ }^{1}$, Yara Essam El-Deen Awad ${ }^{1}$, Salwa M. El-Hallouty ${ }^{2}$, Moustafa El-Araby ${ }^{{ }^{*}}$ \\ ${ }^{1}$ Pharmaceutical Organic Chemistry Department, Faculty of Pharmacy, Helwan University, Cairo, Egypt \\ ${ }^{2}$ Pharmacognosy Department, National Research Centre, Giza, Egypt \\ Email: *alamka@yahoo.com
}

Received June 12, 2012; revised July 15, 2012; accepted July 26, 2012

\begin{abstract}
Starting from 4,6-dimethyl-2-oxo-(1H)-3-pyridinecarbonitrile 1 and 3-aminopyrazolopyridine 4, a series of cyanopyridine derivatives 3a-i, Schiff bases 5a-f, urea and thiourea derivatives 6a-b, amide derivatives 7a-h, pyridopyrazolopyrimidine $8 \mathrm{a}-\mathrm{b}$ and pyridopyrazolotriazine $10 \mathrm{a}-\mathrm{b}$ were synthesized. Activities of eleven representative compounds were evaluated against A-549 (lung), HEPG2 (liver) and HCT-116 (colon) cancer cell lines. The findings revealed that some of the synthesized compounds showed remarkable anticancer activities, especially $8 \mathrm{~b}$ which displayed the highest activity among the tested compounds with $\mathrm{IC}_{50}$ equal to $2.9,2.6$ and $2.3 \mu \mathrm{mol}$. In addition to synthesis and biological activities, we present discussion about the rationale of the design and activity of the potent compound $8 \mathrm{~b}$ using structure-based modeling tools.
\end{abstract}

Keywords: Pyridine; Pyrazolopyridine; Anticancer Activity; CDK Inhibitors; Kinase Inhibitor

\section{Introduction}

Fighting cancer is a non-stop duty for drug researchers [1]. The ultimate triumph is realized when scientists bring to markets oral pills that cure cancer with toxicity as low as aspirin or tylenol (for example). In efforts to help achieving this goal, medicinal chemists and their biology collaborators scored important points in their battles with cancer during the past century. Historically, early chemotherapeutic agents such as classic cytotoxic drugs, antimetabolites, platinum therapy and antibiotics produced adverse effects (AEs) much greater than most of other medications. "Chemo" remained unpleasant experience to the most of cancer patients while the outcome was not always fruitful as chemotherapy just added few months or years to patient life's expectancy [2, $3]$.

The introduction of kinase inhibitors in the beginning of the 21 st century is considered a milestone victory in cancer chemotherapy as safe anticancer oral medications was first made available in world markets [4-6]. The kinase era began upon the introduction of imatinib $\left(\right.$ Glivec $\left.^{\text {TM }}\right)$ in 2001 as selective inhibitor of c-ABL tyrosine kinase (TK) [7,8] (Figure 1). Traditionally, drug discovery programs put emphasis on selectivity issue on the early discovery stage to avoid potential AEs during lead optimization stage and hence, failure of the project.

*Corresponding author. however, search for "laser" selective TK inhibitors has rarely achieved any success, simply because ATP is one ligand for many TKs which all belong to one gene family [8]. Moreover, it was discovered that imatinib hits other kinases such as PDGFR and c-KIT [9]. The reality is that when early TK programs followed the golden principle of the traditional medicinal chemistry "seek high selectivity", it was slow to deliver new anticancer agents. Therefore, most of small molecule kinase programs shifted their strategies to "kill cancer cells" without wasting efforts in solving selectivity dilemma unless it is related to side effects $[10,11]$. The more recent research belongs to new wave of multiple target kinase inhibitors "dirty drugs" represented by Sorafenib, Dasatinib, Sunitinib and Pazopanib (Figure 1) [12]. Still, medicinal chemists must start their projects with designing inhibitors against specific TK targets even though they end-up with significant drug promiscuity [13].

Cyclin-Dependent Kinases (CDKs) are proved to be viable target for development of effective and safe anticancer drugs [14]. For instance, Roscovitine is a CDK-2 inhibitor undergoing clinical trials to treat cancers [15]. Structurally, Roscovitine and other potent CDK inhibitors contained either purine or its bicyclic congeners such as pyrazolopyrimidine and pyrazolopyridazine [16]. For instance, the compound A exhibited excellent CDK2 inhibition but it did not perform well in cancer cell line testing indicating that cell penetration is a challenge to 
the utility of this species of compounds [17]. In the present work, we are introducing compounds that are related to compound A with their inhibitory effect on lung, colon and liver cell lines (Figure 1).

\section{Chemistry}

Synthesis of target compounds were accomplished via key intermediates 3-aminopyrazolopyridine 4 which was prepared in three steps starting from 1, 3-dione derivative and ethyl cyanoacetamide (Scheme 1) according to published method [18]. The intermediate 4 was used as diversity precursor to prepare final compounds belonging to several chemotypes. Therefore, key intermediate 4 was reacted with different appropriate aldehydes to obtain the corresponding imines 5a-f, respectively (Scheme 2).
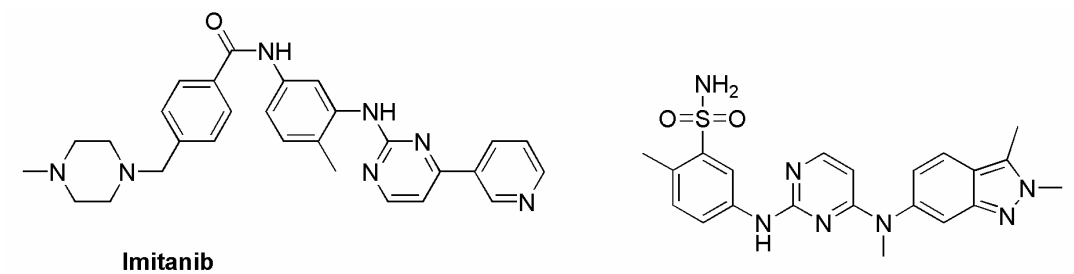

Pazopanib<smiles>CNC(=O)c1cc(Oc2ccc(NC(=O)Nc3ccc(Cl)c(C(F)(F)F)c3)cc2)ccn1</smiles>

Sorafenib<smiles>Cc1nc(Nc2ncc(C(=O)Nc3c(C)cccc3Cl)s2)cc(N2CCN(CCO)CC2)n1</smiles>

Dasatinib

A

Figure 1. Potent anticancer compounds acting by inhibition of various TKs.

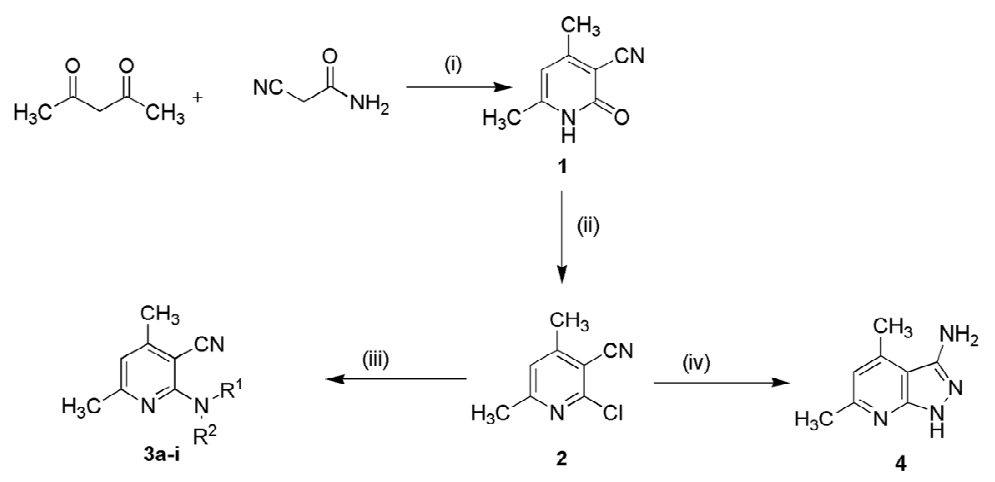

$$
\begin{aligned}
& \text { 3a: } R^{1}=P h, R^{2}=H \\
& \text { 3b: } R^{1}=2-M e P h, R^{2}=H \\
& \text { 3c: } R^{1}=3-M e P h, R^{2}=H \\
& \text { 3d: } R^{1}=4-M e P h, R^{2}=H \\
& \text { 3c: } R^{1}=4 M e O P h, R^{2}=H \\
& \text { 3f: } R^{1}=\mathrm{CH}_{2} P h, R^{2}=H \\
& \text { 3g: } R^{1}=2-C I P h, R^{2}=H \\
& \text { 3h: } R^{1}=4-C I P h, R^{2}=H \\
& \text { 3i: } R^{1}=P h, R^{2}=M e
\end{aligned}
$$

Roscovitine<smiles>CCC(CO)Nc1nc(NCc2ccccc2)c2ncn(C(C)C)c2n1</smiles><smiles>Nc1n[nH]c2nnc(-c3ccccc3)c(-c3ccccc3)c12</smiles>

Scheme 1. Reagent and conditions: (i) $\mathrm{Et}_{3} \mathrm{~N}, \mathrm{EtOH}$, reflux, $5 \mathrm{~h}$; (ii) $\mathrm{POCl}_{3}$, reflux , 5 h; (iii) Amines, $\mathrm{Et}_{3} \mathrm{~N}, \mathrm{reflux}, 5$ h; (iv) $\mathrm{NH}_{2} \mathrm{NH}_{2}$, reflux, $6 \mathrm{~h}$. 


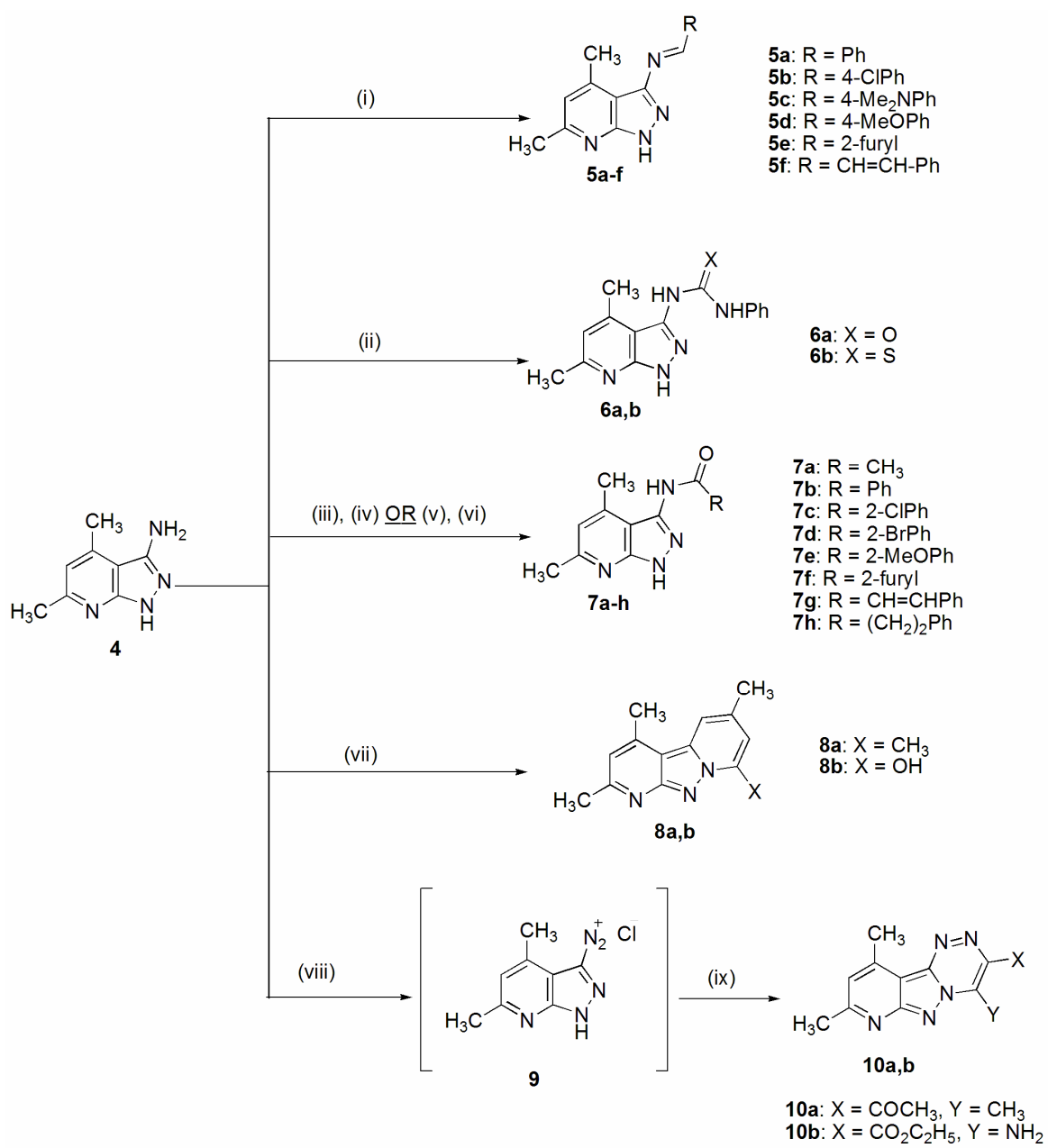

Scheme 2. Reagent and conditions: (i) R-CHO, EtOH, AcOH, reflux, 5h; (ii) isocyanate or isothiocyanate in pyridine, reflux, 5 h; (iii) Acetic anhydride, reflux, 6 h; (iv) PhCOCl, Et3N, CH2Cl2, r.t., 5 h; (v) R-COOH, oxalyl chloride, DMF (cat.), CH2Cl2, r.t., 12 h ; (vi) Et3N, CH2Cl2, rt, 3 h; (vii) Acetylacetone or ethyl acetoacetate, DMF, reflux, 5 hr; (viii) NaNO2, HCl, $0^{\circ} \mathrm{C}, 3 \mathrm{hr}$; (ix) Acetylacetone or ethyl cyanoacetate, $\mathrm{NaOAc}, \mathrm{EtOH}, 0^{\circ} \mathrm{C}, 1 \mathrm{hr}$.

In addition, condensation of the amino pyrazolopyridine 4 with phenyl iso/isothiocyanate in pyridine provided the corresponding phenylurea/thiourea derivatives 6a-b.Another type of compounds was prepared by acylation of 4 to give amides $7 \mathrm{a}-\mathrm{h}$.

Tricyclic derivatives were prepared by condensation of amino pyrazolopyridine 4 with active methylene reagents, namely: acetylacetone or ethyl acetoacetate gave the corresponding pyridopyrazolopyrimidine $8 \mathrm{a}-\mathrm{b}$, respectively. The other tricylic species 10a-b was prepared using a method that involved diazotization of 4 followed by coupling with active methylene-containing reagents [19].

\section{Cancer Cell Line Assays}

\subsection{Materials and Methods}

\subsubsection{Cell Culture}

A-549 (human lung carcinoma), HePG2 (human Liver carcinoma) and HCT-116 (Human Colon carcinoma) were obtained from KarolinskaInstitutet, Stockholm, Sweden. All cells were maintained in RPMI 1640 (LonzaBiowahittkar) medium. All the media were supplemented with $1 \%$ antibiotic-antimycotic mixture $(10,000 \mathrm{U} / \mathrm{ml}$ Potassium Penicillin (Biowest), 10,000 $\mu \mathrm{g} / \mathrm{ml}$ Streptomycin Sulfate (Biowest) and $25 \mu \mathrm{g} / \mathrm{ml}$ Amphotericin B (Biowest) and 1\% L-glutamine (Biowest).

\subsubsection{MTT Cytotoxicity Assay}

The cell viability was investigated using MTT [3-(4,5-dimethylthiazol-2-yl)-2,5-diphenyltetrazolium bromide] assay. This reaction utilizes the mitochondrial-dependent reduction of yellow MTT into purple formazan as indication of cell viability.

All the preceding steps were carried out in sterile laminar flow cabinet biosafety class II level (Baker, SG403INT, Sanford, ME, USA). All incubations were done at $37^{\circ} \mathrm{C}$ in a humidified atmosphere of $5 \% \mathrm{CO}_{2}$ incubator (Sheldon, TC2323, Cornelius, OR, USA). 
Cells were seeded into 96-well microtiterplates at the concentration of $10 \times 103$ and allowed to adhere for 24 hours. Medium was aspirated and a fresh medium (without serum) was added to the cells with various concentrations of compounds $(100,50,10,5,2.5 \& 1.25 \mathrm{ug} / \mathrm{ml})$ and incubated for 48 hours. For the untreated cells (negative control), sterile deionized water was added instead of testedcompounds. A positive control was set usingadrinamycin (doxorubicin) as a known cytotoxic natural agent.

Medium was aspirated and $40 \mu \mathrm{L}$ MTT salt $(2.5 \mu \mathrm{g} / \mathrm{ml})$ (Biobasic Inc.) was added to each well and incubated for further four hours. To stop the reaction and dissolve any formed formazan crystals, $200 \mu \mathrm{L}$ of $10 \%$ Sodium Dodicyl Sulfate (SDS) was added to each well and incubated overnight at $37^{\circ} \mathrm{C}$. The amount of formazan produced was measured at $595 \mathrm{~nm}$ and a reference wave length of $620 \mathrm{~nm}$ as a background using a microplate reader (Bio-Rad Laboratories Inc., model 3350, Hercules, California, USA). The percentage of change in viability was calculated according to the formula: [(Absorbance of compound/Absorbance of negative control) -1$] \times 100$.

A statistical significance was tested between samples and negative control (cells with vehicle) using independent t-test using SPSS 11 software. We have to denote that dimethylsulfoxide (DMSO) is the vehicle used for dissolution of compounds but its final concentration on the cells was less than $0.2 \%$. A probit analysis was carried for $\mathrm{IC}_{50}$ determination using SPSS 11 program.

\subsection{Results}

Results of cancer cellular assays (as summarized in Table 1) illustrate that most of tested compounds showed variable cytotoxic activities. The tricyclic analogue $8 \mathrm{~b}$ showed the highest potency at low $\mu \mathrm{g} / \mathrm{mL}$ level against all cell lines. Other derivatives had lower activities comparable to reference compound as well the tricyclic derivative $8 \mathrm{~b}$.

\section{Discussion}

\subsection{Design and Rationale}

In the preceding work by Braña et al. on pyrazolo $[3,4]$ pyridazine derivative $\mathrm{A}$ and its analogues, it was observed that the cellular activities are not quiet parallel to in vitro enzyme inhibition. The free primary amino group secured good potency in enzyme inhibition but no cellular activities observed for most of compounds. The only compounds in this series that showed activities in both isolated enzyme and cell lines are those with acylated amino group (compounds B, Figure 2); a feature that can be attributed to cell penetration ability of these compounds. However, these two compounds were less potent than the lead compound $\mathrm{A}$ in isolated enzyme assay [17].
Our present work is based on pyrazolo[3,4- $b]$ pyridine scaffold which is a close isoster to Brana's pyrazolo $[3,4-c]$ pyridazine but it has one less nitrogen which was hinted to be less important for binding according to the authors' docking studies.

It is broadly agreed that CDK2 inhibitors are characterized by at least one hydrophobic face of ligands that interact with nonpolar residues patented to this enzyme family [20]. The most frequent nonpolar residues in this region (as appeared in crystal structures) are Leu10, Phe80, Phe82 and Ile83 [21,22]. These residues form a hydrophobic pocket that surround the aminopyrimidine portion (adenine face) of ATP to help binding by reduceing the entropic factors of H-bond formation. In our design, the adenine face's hydrophobic nature has been maintained but small methyl substituents on the pyridine ring were considered (c.f. compounds $\mathrm{A}$ and $\mathrm{B}$ ). The change aimed at sliding the pyridine portion inside the hydrophobic pocket thus allowing more space for accommodating C-3 substituent (Figure 2). In addition, it was envisaged that this movement in ligand will give the pyrazole nitrogens and the $\mathrm{C} 3$ substituents opportunity to make hydrogen bonds with some residues that accommodate the ATP's ribose.

Although the high potency of our compound ( $8 b)$ was surprisingly pleasant to us, it was important to study binding features of this compound using computational tools.

Table 1. Results of cancer cell line inhibition tests.

\begin{tabular}{|c|c|c|c|}
\hline \multirow{2}{*}{ Compound } & \multicolumn{3}{|c|}{$\mathrm{IC}_{50}(\mu \mathrm{g} / \mathrm{mL})$} \\
\hline & A-549 & HepG-2 & HCT-116 \\
\hline 2 & 106.9 & 131.7 & 101.3 \\
\hline $3 e$ & 72.5 & 22.3 & 66.2 \\
\hline 4 & 158.4 & 79.7 & 117.5 \\
\hline $5 d$ & 96.4 & 97.4 & $\mathrm{NA}^{*}$ \\
\hline $5 f$ & 85.6 & 253.1 & NA \\
\hline $6 a$ & 44.7 & 51.04 & 101.3 \\
\hline $6 \mathrm{~b}$ & 105.01 & 128.2 & NA \\
\hline $7 \mathrm{a}$ & 69.9 & 90.4 & NA \\
\hline $7 \mathrm{e}$ & 64.3 & 96.5 & NA \\
\hline $8 \mathrm{~b}$ & 2.9 & 2.6 & 2.3 \\
\hline $10 \mathrm{a}$ & 60.2 & 61.5 & 82.4 \\
\hline Doxorubicin & 2.1 & 2.7 & 4.26 \\
\hline
\end{tabular}

${ }^{*} \mathrm{NA}=$ Compound is not active at tested range. 

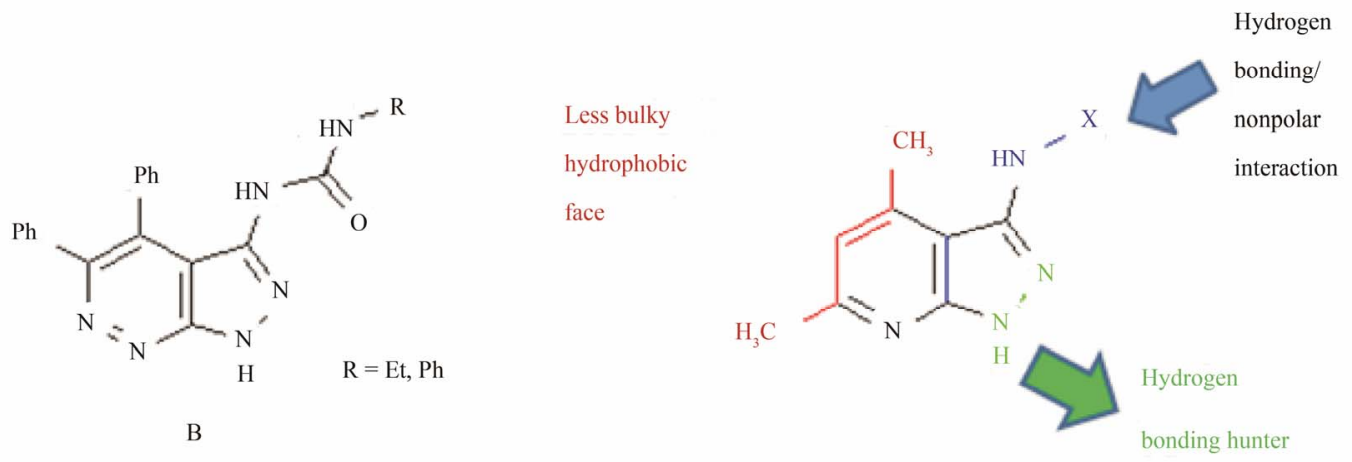

Figure 2. Compounds B are reported as antiproliferative/CDK-2 inhibitor and a sketch for basis of our design.

\subsection{Structure-Based Molecular Modeling of Compound 8b}

Crystal structure of Cyclin-Dependent Kinase 2 (CDK-2) (pdb entry: 1HCK) containing ATP as a ligand was used in modeling experiments without further processing.

Compound $8 \mathrm{~b}$ was constructed on ChemDraw 8.0. Structure was copied to Discovery Studio v. 2.5.5 and saved as Sybyl.mol2 file. The structure was imported to Sybyl-X v. 1.1 and subjected to geometry optimization by running energy minimization.

Parameters of Energy Minimization as follows: Charges: Gasteiger-Marsili Charges; Force Filed: Tripos; Termination: Gradient energy change, $0.01 \mathrm{kcal} / \AA$-mol; rms displacement: $0.001 \AA \AA$; Non-bonded cutoff: $8.000 \AA \AA$; Dielectric function: distant dependent; Dielectric constant: 1.00; Iteration: until convergence.

In the process, ATP and Magnesium were removed from active site and no further optimization was performed because this active site doesn't change significantly upon binding of the ATP. Initial docking of the new ligand $8 \mathrm{~b}$ was in a way that placed pyrazole and pyridine rings of $8 \mathrm{~b}$ completely overlapped with ATP's purine previous position. It was noticed that initial docking is generally acceptable as a starting structure with the exception of some unfavorable approach of one of the methyl groups to the carbonyl of Phe82 and the side chain of Asp145 (Figure 3).

After docking, the new complex was subjected to molecular mechanics (MM) geometry optimization using the above parameters except iterations are limited to 100 . This parameter was enough to optimize the energy of the active site without unnecessary deformations of the protein. As a result, Van der Waal radii became relaxed after minimization without major movement in residues around especially Phe82 and Asp145. However, contacts of the ligand with the active site were not satisfactory as they didn't describe the exceptional activity of $8 \mathrm{~b}$. Therefore, the initial docking complex was subjected to unrestrained molecular dynamics (MD) 100 ps simulations at $298 \mathrm{~K}$ and 1atm. Rest of parameters were set to SYBYL-X default.
Analyzing MD snapshots led to observation of stabilized complex that features important change in the positioning and hence, changes occurred in contacts of the ligand $8 \mathrm{~b}$ with the ah ctive site (Figure 4(a)). The ligand $8 \mathrm{~b}$ responded to MD simulations positively as it established hydrophobic and hydrogen bonding attraction forces with residues around. The most important change is the new bifurcate $\mathrm{H}$-bond between carbonyl of the terminal pyrimidone ring with backbone carbonyl of Gln131 and side chain amide of Asn132. It was also noticed that residues of adenine pocket approached the dimethylpyridine portion of the ligand in suitable $\mathrm{VdW}$ distances. In addition, some favorable hydrophobic contacts of the methyl group on the pyrimidone ring with Val18 and Phe80 appeared. To confirm the validity of the MD algorithms, we extracted the ligand $8 \mathrm{~b}$ from the MD snapshot and redocked it into CDK-2 active site without energy optimizations (Figure 4(b)). It was noticed that interactions of the ligand with residues especially Gln131 and Asn132 are identical to those obtained from MD simulations.

\section{Conclusion}

Compounds belonging to this class of compounds exhibited moderate to potent anticancer activities in cell line tests. The safety of these compounds was preliminarily investigated by acute mice toxicity test. None of the tested compounds caused death of the animals in doses up to $500 \mathrm{mg} / \mathrm{kg}$. The most potent compound $8 \mathrm{~b}$ is characterized by restrained side chain indicating the small space around this area in kinase active sites. In addition, the loss of potency occurred upon changing the $\mathrm{OH}$ group by amino either due to decrease of cellular penetration or inability of making effective electrostatic contacts with the active site as in $8 \mathrm{~b}$. Further SAR studies are needed for $8 \mathrm{~b}$ especially on the hydrophobic side.

\section{Experimental}

\section{General Methods}

All melting points were uncorrected and measured using 


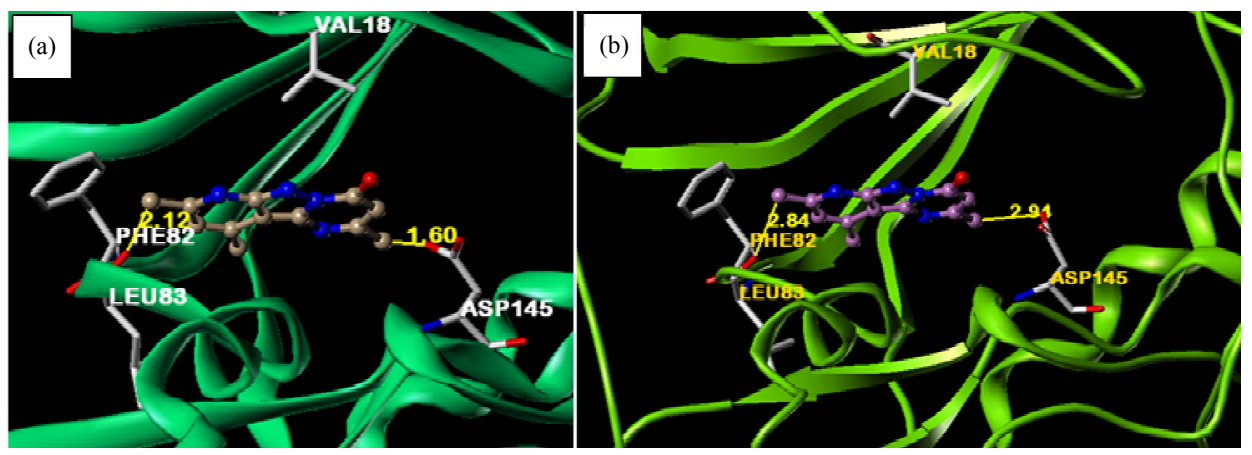

Figure 3. (a) Initial docking of $8 \mathrm{~b}$ by complete overlap with ATP purine bicyclic structure. Note unfavorable contacts with Phe82 and Asp145; (b) 8b docked to active site after energy minimization (applying of MM).
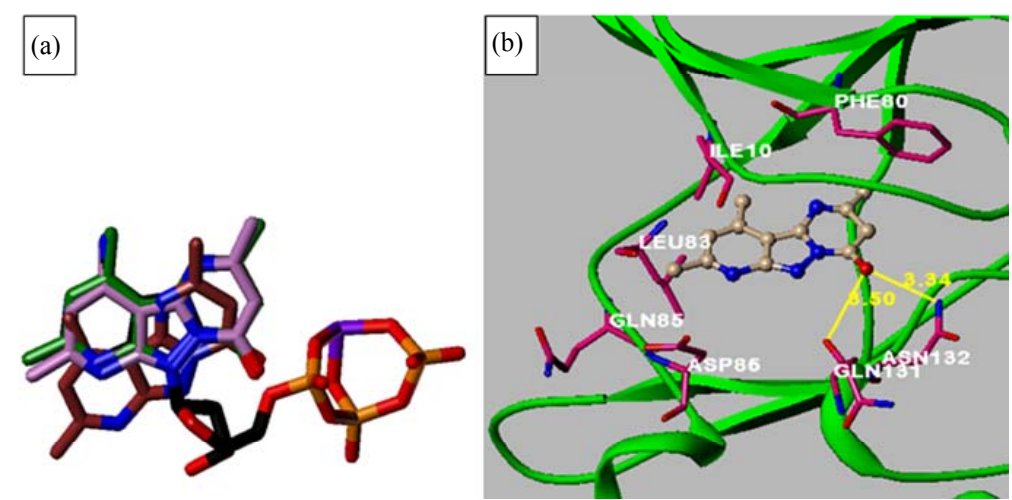

Figure 4. (a) Alignement of ATP (black) extracted from CDK-2 with 8b after docking. Initial docking position of 8b is shown in green; after applying MM is shown in violet; and after MD imulations is shown in brown.position from docking position (magenta) to position after applying molecular mechanics (green) and position after applying molecular dymanics (light brown); (b) Contacts of $8 \mathrm{~b}$ with active site after second docking experiments based on results of MD simulations.

Electro-thermal IA 9100 apparatus (Shimadzu, Japan); IR spectra were recorded as potassium bromide pellets on a Perkin-Elmer 1650 spectrophotometer (USA), Faculty of Science, Cairo University, Cairo, Egypt. ${ }^{1} \mathrm{H}-$ NMR spectra were determined on a Varian Mercury (500 $\mathrm{MHz}$ ) spectrometer (Varian UK) and chemical shifts were expressed as ppm against TMS as internal reference (Faculty of Science, Cairo University, Cairo, Egypt). Mass spectra were recorded on $70 \mathrm{eV}$ (EI Ms-QP 1000 EX, Shimadzu, Japan), Faculty of Science, Cairo University, Cairo, Egypt. Microanalyses were operated using Vario, Elmentar apparatus (Shimadzu, Japan), Organic Microanalysis Unit, Cairo University, Giza, Egypt. Column Chromatography was performed on (Merck) Silica gel 60 (particle size $0.06 \mathrm{~mm}-0.20 \mathrm{~mm}$ ). All compounds prepared in this paper are new and confirmed with spectral data.

4,6-Dimethyl-2-oxo-(1H)-3-pyridinecarbonitrile (1)

A mixture of cyanoacetamide $(0.01 \mathrm{~mol})$ and acetyl acetone $(0.01 \mathrm{~mol})$ in ethanol $(20 \mathrm{~mL})$ and triethylamine $(1 \mathrm{~mL})$ was heated under the reflux for $6 \mathrm{~h}$, poured, onto cold water. The obtained precipitate was filtered off, washed with ethanol and re-crystallized from methanol to afford 1.

Yield $89 \%$, m.p. $290^{\circ} \mathrm{C}$ (Lit. mp. $290^{\circ} \mathrm{C}-292^{\circ} \mathrm{C}$ [18]).

2-Chloro-4,6-dimethyl-3-pyridinecarbonitrile (2)

A mixture of 2-pyridone $1(0.01 \mathrm{~mol})$ and $\mathrm{POCl}_{3}(20$ $\mathrm{mL}$ ) was heated under the reflux for $6 \mathrm{~h}$, cooled, poured onto crushed ice with stirring to give a precipitate which was filtered off, air dried, and re-crystallized from methanol to afford 2.

Yield $91 \%$, m.p. $90^{\circ} \mathrm{C}$ (Lit. mp. $90^{\circ} \mathrm{C}-92^{\circ} \mathrm{C}[18]$ ).

General procedure for the synthesis of compounds (3a-i)

A mixture of 2-chloro pyridine $2(0.01 \mathrm{~mol})$ and appropriate amine $(0.04 \mathrm{~mol})$, namely: aniline, 2-toluidine, 3-toluidine, 4-toluidine, 4-anisidine, benzylamine, 2-chloroaniline, 4-chloroaniline, $N$-methylaniline in ethanol (30 $\mathrm{mL}$ ) was stirred at $100^{\circ} \mathrm{C}$ for $48 \mathrm{~h}$ in a sealed tube. The reaction mixture gave a precipitate which was filtered, washed with EtOH and dried under vacuum to afford 3a-i.

4,6-Dimethyl-2-(phenylamino)pyridine-3-carbonitri le (3a)

Yield $87 \%$, m.p. $277^{\circ} \mathrm{C}-279^{\circ} \mathrm{C}$, IR $(\mathrm{KBr}) v\left(\mathrm{~cm}^{-1}\right)$ : $3350(\mathrm{NH}), 2230(\mathrm{C} \equiv \mathrm{N})$. MS (EI) $m / z: 223\left(\mathrm{M}^{+}, 91 \%\right)$. 
${ }^{1} \mathrm{H}$ NMR (DMSO- $\left.d_{6}\right)(500 \mathrm{MHz}) \delta$ (ppm): 2.59 (s, $3 \mathrm{H}$, $\left.\mathrm{CH}_{3}\right), 2.65\left(\mathrm{~s}, 3 \mathrm{H}, \mathrm{CH}_{3}\right), 4.85$ (s, $1 \mathrm{H}, \mathrm{NH}, \mathrm{D}_{2} \mathrm{O}$ exchangeable), 6.8 (s, $1 \mathrm{H}, \mathrm{C} 5-\mathrm{H}), 7.1-7.6(\mathrm{~m}, 5 \mathrm{H}, \mathrm{Ar}-\mathrm{H})$. Anal. Calcd for $\mathrm{C}_{14} \mathrm{H}_{13} \mathrm{~N}_{3}$ (223.27): C, 75.31; H, 5.87; N, 18.82. Found: C, 75.54; H, 6.10; N, 18.58 .

4,6-Dimethyl-2-(2-methylphenylamino)-pyridine-3carbonitrile (3b)

Yield $83 \%$, m.p. $220-222^{\circ} \mathrm{C}$, IR $(\mathrm{KBr}) v\left(\mathrm{~cm}^{-1}\right): 3270$ $(\mathrm{NH}), 2225(\mathrm{C} \equiv \mathrm{N})$. MS (EI) $m / z: 237\left(\mathrm{M}^{+}, 89 \%\right) .{ }^{1} \mathrm{H}$ NMR (DMSO- $\left.d_{6}\right)(500 \mathrm{MHz}) \delta(\mathrm{ppm}): 2.35\left(\mathrm{~s}, 3 \mathrm{H}, \mathrm{CH}_{3}\right)$, $2.65\left(\mathrm{~s}, 3 \mathrm{H}, \mathrm{CH}_{3}\right), 2.75\left(\mathrm{~s}, 3 \mathrm{H}, \mathrm{CH}_{3}\right), 4.5(\mathrm{~s}, 1 \mathrm{H}, \mathrm{NH}$, $\mathrm{D}_{2} \mathrm{O}$ exchangeable), $6.8(\mathrm{~s}, 1 \mathrm{H}, \mathrm{C} 5-\mathrm{H}), 7.2-7.8(\mathrm{~m}, 4 \mathrm{H}$, Ar-H). Anal. Calcd for $\mathrm{C}_{15} \mathrm{H}_{15} \mathrm{~N}_{3}$ (237.3): C, 75.92; H, 6.37; N, 17.71. Found: C, 75.70; H, 6.59; N, 17.48 .

4,6-Dimethyl-2-(3-methylphenylamino)-pyridine-3carbonitrile (3c)

Yield $75 \%$, m.p. $110^{\circ} \mathrm{C}-112^{\circ} \mathrm{C}$, IR $(\mathrm{KBr}) v\left(\mathrm{~cm}^{-1}\right)$ : $3320(\mathrm{NH}), 2235(\mathrm{C} \equiv \mathrm{N})$. MS (EI) $m / z: 237\left(\mathrm{M}^{+}, 67 \%\right)$. ${ }^{1} \mathrm{H}$ NMR (DMSO- $\left.d_{6}\right)(500 \mathrm{MHz}) \delta(\mathrm{ppm}): 2.4(\mathrm{~s}, 3 \mathrm{H}$, $\left.\mathrm{CH}_{3}\right), 2.55\left(\mathrm{~s}, 3 \mathrm{H}, \mathrm{CH}_{3}\right), 2.66\left(\mathrm{~s}, 3 \mathrm{H}, \mathrm{CH}_{3}\right), 4.6(\mathrm{~s}, 1 \mathrm{H}$, $\mathrm{NH}, \mathrm{D}_{2} \mathrm{O}$ exchangeable), 6.7 (s, $\left.1 \mathrm{H}, \mathrm{C} 5-\mathrm{H}\right), 7.4$ - 7.9 (m, 4H, Ar-H). Anal. Calcd for $\mathrm{C}_{15} \mathrm{H}_{15} \mathrm{~N}_{3}$ (237.3): C, 75.92; H, 6.37; N, 17.71. Found: C, 75.78; H, 6.22; N, 17.62.

4,6-Dimethyl-2-(4-methylphenylamino)-pyridine-3-c arbonitrile (3d)

Yield $91 \%$, m.p. $160^{\circ} \mathrm{C}-162^{\circ} \mathrm{C}$, IR $(\mathrm{KBr}) v\left(\mathrm{~cm}^{-1}\right)$ : $3340(\mathrm{NH}), 2230(\mathrm{C} \equiv \mathrm{N})$. MS (EI) $m / z: 237\left(\mathrm{M}^{+}, 75 \%\right)$. ${ }^{1} \mathrm{H}$ NMR (DMSO- $\left.d_{6}\right)(500 \mathrm{MHz}) \delta(\mathrm{ppm}): 2.31(\mathrm{~s}, 3 \mathrm{H}$, $\left.\mathrm{CH}_{3}\right), 2.60\left(\mathrm{~s}, 3 \mathrm{H}, \mathrm{CH}_{3}\right), 2.72\left(\mathrm{~s}, 3 \mathrm{H}, \mathrm{CH}_{3}\right), 4.4(\mathrm{~s}, 1 \mathrm{H}$, $\mathrm{NH}, \mathrm{D}_{2} \mathrm{O}$ exchangeable), $6.34-6.74(\mathrm{dd}, 4 \mathrm{H}, \mathrm{Ar}-\mathrm{H})$, 6.8(s, $1 \mathrm{H}, \mathrm{C} 5-\mathrm{H})$. Anal. Calcd for $\mathrm{C}_{15} \mathrm{H}_{15} \mathrm{~N}_{3}$ (237.3): C, 75.92; H, 6.37; N, 17.71. Found: C, 75.80; H, 6.54; N, 17.95 .

2-(4-Methoxyphenylamino)-4,6-dimethylpyridine-3carbonitrile (3e)

Yield $84 \%$, m.p. $105^{\circ} \mathrm{C}-107^{\circ} \mathrm{C}$, IR $(\mathrm{KBr}) v\left(\mathrm{~cm}^{-1}\right)$ : $3160(\mathrm{NH}), 2211(\mathrm{C} \equiv \mathrm{N})$. MS (EI) $\mathrm{m} / z: 253\left(\mathrm{M}^{+}, 86 \%\right)$. ${ }^{1} \mathrm{H}$ NMR (DMSO- $\left.d_{6}\right)(500 \mathrm{MHz}) \delta(\mathrm{ppm}): 2.40(\mathrm{~s}, 3 \mathrm{H}$, $\left.\mathrm{CH}_{3}\right), 2.72$ (s, $\left.3 \mathrm{H}, \mathrm{CH}_{3}\right), 3.75$ (s, $\left.3 \mathrm{H}, \mathrm{O}-\mathrm{CH}_{3}\right), 4.5$ (s, 1 $\mathrm{H}, \mathrm{NH}, \mathrm{D}_{2} \mathrm{O}$ exchangeable), $6.7(\mathrm{~s}, 1 \mathrm{H}, \mathrm{C} 5-\mathrm{H}), 7.35-$ 7.58 (dd, $4 \mathrm{H}, \mathrm{Ar}-\mathrm{H}$ ). Anal. Calcd for $\mathrm{C}_{15} \mathrm{H}_{15} \mathrm{~N}_{3} \mathrm{O}(253.3)$ : C, 71.13; H, 5.97; N, 16.59; O, 6.32. Found: C, 71.32; H, $6.21 ; \mathrm{N}, 16.72 ; \mathrm{O}, 6.58$. (3f)

2-(Benzylamino)-4,6-dimethylpyridine-3-carbonitrile

Yield $69 \%$, m.p. $140^{\circ} \mathrm{C}-142^{\circ} \mathrm{C}$, IR $(\mathrm{KBr}) v\left(\mathrm{~cm}^{-1}\right)$ : $3260(\mathrm{NH}), 2230(\mathrm{C} \equiv \mathrm{N})$. MS (EI) $m / z: 237\left(\mathrm{M}^{+}, 88.0 \%\right)$. ${ }^{1} \mathrm{H}$ NMR (DMSO- $\left.d_{6}\right)(500 \mathrm{MHz}) \delta(\mathrm{ppm}): 2.3(\mathrm{~s}, 3 \mathrm{H}$, $\left.\mathrm{CH}_{3}\right), 2.55\left(\mathrm{~s}, 3 \mathrm{H}, \mathrm{CH}_{3}\right), 4.7\left(\mathrm{~s}, 2 \mathrm{H}, \mathrm{CH}_{2}\right), 6.2(\mathrm{~s}, 1 \mathrm{H}$, $\mathrm{NH}, \mathrm{D}_{2} \mathrm{O}$ exchangeable), 6.8(s, $\left.1 \mathrm{H}, \mathrm{C} 5-\mathrm{H}\right), 7.15-7.0$ (m, $5 \mathrm{H}$, Ar-H). Anal. Calcd for $\mathrm{C}_{15} \mathrm{H}_{15} \mathrm{~N}_{3}$ (237.3): C, 75.92; H, 6.37; N, 17.71. Found: C, 75.70; H, 6.59; N, 17.48.

2-(2-Chlorophenylamino)-4,6-dimethylpyridine-3-c arbonitrile (3g)
Yield $71 \%$, m.p. $100^{\circ} \mathrm{C}-102^{\circ} \mathrm{C}$, IR $(\mathrm{KBr}) v\left(\mathrm{~cm}^{-1}\right)$ : $3330(\mathrm{NH}), 2225(\mathrm{C} \equiv \mathrm{N})$. MS (EI) $\mathrm{m} / \mathrm{z}: 257\left(\mathrm{M}^{+},{ }^{35} \mathrm{Cl}\right.$, $56 \%), 259\left(\mathrm{M}^{+}+2,{ }^{37} \mathrm{Cl}, 17.6 \%\right) .{ }^{1} \mathrm{H}$ NMR (DMSO- $\left.d_{6}\right)$ $(500 \mathrm{MHz}) \delta(\mathrm{ppm}): 2.29\left(\mathrm{~s}, 3 \mathrm{H}, \mathrm{CH}_{3}\right), 2.53(\mathrm{~s}, 3 \mathrm{H}$, $\left.\mathrm{CH}_{3}\right), 4.62\left(\mathrm{~s}, 1 \mathrm{H}, \mathrm{NH}, \mathrm{D}_{2} \mathrm{O}\right.$ exchangeable), $6.8(\mathrm{~s}, 1$ $\mathrm{H}, \mathrm{C} 5-\mathrm{H})$, 7.5-7.0 (m, $4 \mathrm{H}$, Ar-H). Anal. Calcd for $\mathrm{C}_{14} \mathrm{H}_{12} \mathrm{ClN}_{3}$ (257.72): C, 65.25; H, 4.69; $\mathrm{Cl}, 13.76 ; \mathrm{N}$, 16.30. Found: C, 65.48; H, 4.89; Cl, 13.91; N, 16.54.

2-(4-Chlorophenylamino)-4,6-dimethylpyridine-3-c arbonitrile (3h)

Yield $69 \%$, m.p. $190^{\circ} \mathrm{C}-192^{\circ} \mathrm{C}$, IR $(\mathrm{KBr}) v\left(\mathrm{~cm}^{-1}\right)$ : $3260.1(\mathrm{NH}), 2218(\mathrm{C} \equiv \mathrm{N})$. MS (EI) $m / z: 257\left(\mathrm{M}^{+},{ }^{35} \mathrm{Cl}\right.$, $78.2 \%), 259\left(\mathrm{M}^{+}+2,{ }^{37} \mathrm{Cl}, 25.5 \%\right) .{ }^{1} \mathrm{H}$ NMR (DMSO- $\left.d_{6}\right)$ $(500 \mathrm{MHz}) \delta(\mathrm{ppm}): 2.36\left(\mathrm{~s}, 3 \mathrm{H}, \mathrm{CH}_{3}\right), 2.72(\mathrm{~s}, 3 \mathrm{H}$, $\left.\mathrm{CH}_{3}\right), 5.2\left(\mathrm{~s}, 1 \mathrm{H}, \mathrm{NH}, \mathrm{D}_{2} \mathrm{O}\right.$ exchangeable), $6.8(\mathrm{~s}, 1 \mathrm{H}$, C5-H), 6.4, 7.2 (dd, $4 \mathrm{H}$, Ar-H). Anal. Calcd for $\mathrm{C}_{14} \mathrm{H}_{12} \mathrm{ClN}_{3}$ (257.72): $\mathrm{C}, 65.25 ; \mathrm{H}, 4.69 ; \mathrm{Cl}, 13.76 ; \mathrm{N}$, 16.30. Found: C, 65.48; H, 4.82; Cl, 13.51; N, 16.48 .

2-( $N$-Methyl- $N$-phenylamino)-4,6-dimethylpyridine3-carbonitrile (3i)

Yield $74 \%$, m.p. $110^{\circ} \mathrm{C}-112^{\circ} \mathrm{C}$, IR $(\mathrm{KBr}) v\left(\mathrm{~cm}^{-1}\right)$ : $2232(\mathrm{C} \equiv \mathrm{N})$. MS (EI) $\mathrm{m} / z: 237\left(\mathrm{M}^{+}, 38.8 \%\right) .{ }^{1} \mathrm{H}$ NMR $\left(\right.$ DMSO- $\left.d_{6}\right)(500 \mathrm{MHz}) \delta(\mathrm{ppm}): 2.39\left(\mathrm{~s}, 3 \mathrm{H}, \mathrm{CH}_{3}\right), 2.57$ (s, $\left.3 \mathrm{H}, \mathrm{CH}_{3}\right), 3.6\left(\mathrm{~s}, 3 \mathrm{H}, \mathrm{N}-\mathrm{CH}_{3}\right), 6.7(\mathrm{~s}, 1 \mathrm{H}, \mathrm{C} 5-\mathrm{H}), 6.9$ - 7.4 (m, $5 \mathrm{H}, \mathrm{Ar}-\mathrm{H})$. Anal. Calcd for $\mathrm{C}_{15} \mathrm{H}_{15} \mathrm{~N}_{3}$ (237.3): C, 75.92; H, 6.37; N, 17.71. Found: C, 75.73; H, 6.54; N, 17.92 .

(4)

4,6-Dimethyl-1H-pyrazolo[3,4-b]pyridin-3-amine

A mixture of 2-chloro pyridine $2(0.01 \mathrm{~mol})$ and hydrazine hydrate $(99 \%, 0.03 \mathrm{~mol})$ in absolute ethanol $(20$ $\mathrm{mL}$ ) was heated under reflux for $6 \mathrm{~h}$. The reaction mixture was concentrated to one third of its volume. The product that formed was collected by filtration, washed with cold ethanol, and then crystallized from ethanol to afford 4.

Yield $95 \%$, m.p. $280^{\circ} \mathrm{C}-282^{\circ} \mathrm{C}$ (Lit. mp. $280^{\circ} \mathrm{C}$ [18]).

General procedure for the synthesis of compounds (5a-f)

A mixture of 3-amino pyrazolopyridine $4(0.01 \mathrm{~mol})$ and the appropriate aldehyde, namely: benzaldehyde, 4-chlorobenzaldehyde, 4-dimethylaminobenzaldhyde, $p$ anisaldehyde, furfural and cinnamaldhde $(0.01 \mathrm{~mol})$ in absolute ethanol $(30 \mathrm{~mL})$ containing few drops glacial acetic acid, was refluxed for $5 \mathrm{~h}$. The reaction mixture was cooled and poured onto ice. The solid formed was filtered off, washed with water and re-crystallized from the methanol to afford Schiff bases 5a-f.

$N$-Benzylidene-4,6-dimethyl-1 $H$-pyrazolo $[3,4-b]$ pyridine-3-amine (5a)

Yield $72 \%$, m.p. $245^{\circ} \mathrm{C}-247^{\circ} \mathrm{C}$, IR $(\mathrm{KBr}) v\left(\mathrm{~cm}^{-1}\right)$ : $3265(\mathrm{NH}), 1320(\mathrm{C}=\mathrm{N})$. MS (EI) $\mathrm{m} / z: 250\left(\mathrm{M}^{+}, 58.9 \%\right)$. ${ }^{1} \mathrm{H}$ NMR (DMSO- $\left.d_{6}\right)(500 \mathrm{MHz}) \delta(\mathrm{ppm}): 2.36(\mathrm{~s}, 3 \mathrm{H}$, $\left.\mathrm{CH}_{3}\right), 2.72\left(\mathrm{~s}, 3 \mathrm{H}, \mathrm{CH}_{3}\right), 6.8(\mathrm{~s}, 1 \mathrm{H}, \mathrm{C} 5-\mathrm{H}), 7.3$ - $7.6(\mathrm{~m}$, 
5H, Ar-H), 8.1 (s, $1 \mathrm{H}, \mathrm{CH}), 13.0$ (s, $1 \mathrm{H}, \mathrm{NH}$, pyrazole, $\mathrm{D}_{2} \mathrm{O}$ exchangeable). Anal. Calcd for $\mathrm{C}_{15} \mathrm{H}_{14} \mathrm{~N}_{4}(250.3)$ : $\mathrm{C}$, 71.98; H, 5.64; N, 22.38. Found: C, 71.68; H, 5.41; N, 22.59 .

$\mathrm{N}$-(4-Chlorobenzylidene)-4,6-dimethyl-1H-pyrazolo [3,4-b]pyridine-3-amine (5b)

Yield $79 \%$, m.p. $290^{\circ} \mathrm{C}-292^{\circ} \mathrm{C}$, IR $(\mathrm{KBr}) v\left(\mathrm{~cm}^{-1}\right)$ : $3290(\mathrm{NH}), 1350(\mathrm{C}=\mathrm{N})$. MS (EI) $\mathrm{m} / z: 284\left(\mathrm{M}^{+},{ }^{35} \mathrm{Cl}\right.$, 49.5\%), $286\left(\mathrm{M}^{+}+2,{ }^{37} \mathrm{Cl}, 16.5 \%\right) .{ }^{1} \mathrm{H}$ NMR (DMSO- $\left.d_{6}\right)$ (500 MHz) $\delta$ (ppm): $2.42\left(\mathrm{~s}, 3 \mathrm{H}, \mathrm{CH}_{3}\right), 2.68(\mathrm{~s}, 3 \mathrm{H}$, $\left.\mathrm{CH}_{3}\right), 6.8$ (s, $\left.1 \mathrm{H}, \mathrm{C} 5-\mathrm{H}\right), 7.3,7.6$ (dd, $\left.4 \mathrm{H}, \mathrm{Ar}-\mathrm{H}\right), 7.9$ (s, $1 \mathrm{H}, \mathrm{CH}), 13.0$ (s, H, NH, pyrazole, $\mathrm{D}_{2} \mathrm{O}$ exchangeable). Anal. Calcd for $\mathrm{C}_{15} \mathrm{H}_{13} \mathrm{ClN}_{4}$ (284.74): C, 63.27; H, 4.60; Cl, 12.45; N, 19.68. Found: C, 63.43; H, 4.85; Cl, 12.62; N, 19.39 .

$N$-[4-(Dimethylamino)benzylidene]-4,6-dimethyl-1 $H$-pyrazolo[3,4-b]pyridine-3-amine (5c)

Yield $65 \%$, m.p. $230^{\circ} \mathrm{C}-232^{\circ} \mathrm{C}$, IR $(\mathrm{KBr}) v\left(\mathrm{~cm}^{-1}\right)$ : $3280(\mathrm{NH}), 1260(\mathrm{C}=\mathrm{N})$. MS (EI) $m / z: 293\left(\mathrm{M}^{+}, 85 \%\right) .{ }^{1} \mathrm{H}$ NMR (DMSO- $\left.d_{6}\right)(500 \mathrm{MHz}) \delta(\mathrm{ppm}): 2.42(\mathrm{~s}, 3 \mathrm{H}$, $\left.\mathrm{CH}_{3}\right), 2.68\left(\mathrm{~s}, 3 \mathrm{H}, \mathrm{CH}_{3}\right), 3.2\left(\mathrm{~s}, 6 \mathrm{H}, \mathrm{CH}_{3}\right), 6.9(\mathrm{~s}, 1 \mathrm{H}$, C5-H), 7.3 (d, 2H, Ar-H), 7.6 (d, 2H, Ar-H), 8.34 (s, $1 \mathrm{H}$, $\mathrm{CH}), 13.0$ (s, H, NH, pyrazole, $\mathrm{D}_{2} \mathrm{O}$ exchangeable). Anal. Calcd for $\mathrm{C}_{17} \mathrm{H}_{19} \mathrm{~N}_{5}$ (293.37): C, 69.60; H, 6.53; N, 23.87. Found: C, 69.87; H, 6.78; N, 23.61.

$\mathrm{N}$-(4-Methoxybenzylidene)-4,6-dimethyl-1H-pyrazo lo [3, 4-b]pyridine-3-amine (5d)

Yield $84 \%$, m.p. $250^{\circ} \mathrm{C}-252^{\circ} \mathrm{C}$, IR $(\mathrm{KBr}) v\left(\mathrm{~cm}^{-1}\right)$ : $3142(\mathrm{NH}), 1310(\mathrm{C}=\mathrm{N}), 1250(\mathrm{C}-\mathrm{O})$. MS (EI) $m / z: 280$ $\left(\mathrm{M}^{+}, 41 \%\right) .{ }^{1} \mathrm{H}$ NMR (DMSO- $\left.d_{6}\right)(500 \mathrm{MHz}) \delta(\mathrm{ppm})$ : $2.35\left(\mathrm{~s}, 3 \mathrm{H}, \mathrm{CH}_{3}\right), 2.72\left(\mathrm{~s}, 3 \mathrm{H}, \mathrm{CH}_{3}\right), 3.7(\mathrm{~s}, 3 \mathrm{H}$, $\left.\mathrm{O}-\mathrm{CH}_{3}\right), 6.8$ (s, $\left.1 \mathrm{H}, \mathrm{C} 5-\mathrm{H}\right), 7.2,7.2$ (d, 2H, Ar-H), 7.5 (d, 2H, Ar-H), 8.02 (s, $1 \mathrm{H}, \mathrm{CH}), 13.0$ (s, H, NH, pyrazole, $\mathrm{D}_{2} \mathrm{O}$ exchangeable). Anal. Calcd for $\mathrm{C}_{16} \mathrm{H}_{16} \mathrm{~N}_{4} \mathrm{O}$ (280.32): C, 68.55; H, 5.75; N, 19.99; O, 5.71. Found: C, 68.81; H, $5.94 ; \mathrm{N}, 19.75 ; \mathrm{O}, 5.49$.

$\mathrm{N}$-[(Furan-2-yl)methylene]-4,6-dimethyl-1H-pyrazolo [3,4-b]pyridine-3-amine (5e)

Yield $63 \%$, m.p. $235^{\circ} \mathrm{C}-237^{\circ} \mathrm{C}$, IR $(\mathrm{KBr}) v\left(\mathrm{~cm}^{-1}\right)$ : $3230(\mathrm{NH}), 1250(\mathrm{C}=\mathrm{N})$. MS (EI) $m / z: 240\left(\mathrm{M}^{+}, 54 \%\right)$. ${ }^{1} \mathrm{H}$ NMR (DMSO- $\left.d_{6}\right)(500 \mathrm{MHz}) \delta(\mathrm{ppm}): 2.46$ (s, $3 \mathrm{H}$, $\left.\mathrm{CH}_{3}\right), 2.71\left(\mathrm{~s}, 3 \mathrm{H}, \mathrm{CH}_{3}\right), 6.9(\mathrm{~s}, 1 \mathrm{H}, \mathrm{C} 5-\mathrm{H}), 7.3$ - 7.5 (m, $3 \mathrm{H}$, furan- $\mathrm{H}), 8.0(\mathrm{~s}, 1 \mathrm{H}, \mathrm{CH}), 13.0(\mathrm{~s}, \mathrm{H}, \mathrm{NH}$, pyrazole, $\mathrm{D}_{2} \mathrm{O}$ exchangeable). Anal. Calcd for $\mathrm{C}_{13} \mathrm{H}_{12} \mathrm{~N}_{4} \mathrm{O}(240.26)$ : C, 64.99; H, 5.03; N, 23.32; O, 6.66. Found: C, 64.72; H, $5.25 ; \mathrm{N}, 23.59 ; \mathrm{O}, 6.84$.

(E)-4,6-Dimethyl- $N$-(3-phenylallylidene)-1H-pyrazolo [3,4-b]pyridin-3-amine (5f)

Yield $81 \%$, m.p. $135^{\circ} \mathrm{C}-137^{\circ} \mathrm{C}$, IR $(\mathrm{KBr}) v\left(\mathrm{~cm}^{-1}\right)$ : $3142(\mathrm{NH}), 1210(\mathrm{C}=\mathrm{N})$. MS (EI) $m / z: 276\left(\mathrm{M}^{+}, 83.5 \%\right)$. ${ }^{1} \mathrm{H}$ NMR (DMSO- $\left.d_{6}\right)(500 \mathrm{MHz}) \delta(\mathrm{ppm}): 2.25$ (s, $3 \mathrm{H}$, $\left.\mathrm{CH}_{3}\right), 2.62\left(\mathrm{~s}, 3 \mathrm{H}, \mathrm{CH}_{3}\right), 6.8(\mathrm{~s}, 1 \mathrm{H}, \mathrm{C} 5-\mathrm{H}), 7.1$ - $7.4(\mathrm{~m}$, $5 \mathrm{H}, \mathrm{Ar}-\mathrm{H}), 8.3(\mathrm{~d}, 1 \mathrm{H}, \mathrm{CH}=\mathrm{N}), 8.8(\mathrm{t}, 1 \mathrm{H}, \mathrm{CH}=\mathrm{CH})$, 9.6 (d, $1 \mathrm{H}, \mathrm{CH}-\mathrm{ph}), 13.0$ (s, H, NH, pyrazole, $\mathrm{D}_{2} \mathrm{O}$ ex- changeable). Anal. Calcd for $\mathrm{C}_{17} \mathrm{H}_{16} \mathrm{~N}_{4}$ (276.34): $\mathrm{C}$, 73.89; H, 5.84; N, 20.27. Found: C, 73.62; H, 5.59; N, 20.12 .

General procedure for the synthesis of compounds (6a-b)

A mixture of 3-amino pyrazolopyridine $4(0.01 \mathrm{~mol})$ and phenylisocyanate or phenylisothiocyanate $(0.01 \mathrm{~mol})$ in pyridine $(20 \mathrm{~mL})$ was refluxed for $5 \mathrm{~h}$. The reaction mixture was poured on to crushed ice containing few drops of $\mathrm{HCl}$. The solid product was filtered off and crystallized from acetic acid to afford $6 a-b$.

1-(4,6-Dimethyl-1H-pyrazolo[3,4-b]pyridin-3-yl)-3phenylurea (6a)

Yield $83 \%$, m.p. $250^{\circ} \mathrm{C}-252^{\circ} \mathrm{C}$, IR $(\mathrm{KBr}) v\left(\mathrm{~cm}^{-1}\right)$ : 3321, 3275 and $3123(\mathrm{NH}), 1690(\mathrm{C}=\mathrm{O})$. MS (EI) $\mathrm{m} / \mathrm{z}$ : $281\left(\mathrm{M}^{+}, 45 \%\right) .{ }^{1} \mathrm{H}$ NMR (DMSO-d $)(500 \mathrm{MHz}) \delta$ (ppm): 2.32 (s, $\left.3 \mathrm{H}, \mathrm{CH}_{3}\right), 2.49\left(\mathrm{~s}, 3 \mathrm{H}, \mathrm{CH}_{3}\right), 6.8(\mathrm{~s}, 1 \mathrm{H}$, C5-H), 7.3 - 7.64 (m, 5 H, Ar-H), 8.5, 7.9 (s, 2 H, 2 NH, $\mathrm{D}_{2} \mathrm{O}$ exchangeable), 13.0 (s, H, NH, pyrazole, $\mathrm{D}_{2} \mathrm{O}$ exchangeable). Anal. Calcd for $\mathrm{C}_{15} \mathrm{H}_{15} \mathrm{~N}_{5} \mathrm{O}$ (281.13): $\mathrm{C}$, 64.04; H, 5.37; N, 24.90; O, 5.69. Found: C, 64.29; H, $5.13 ; \mathrm{N}, 24.73 ; \mathrm{O}, 5.91$.

1-(4,6-Dimethyl-1H-pyrazolo[3,4-b]pyridin-3-yl)-3phenylthiourea (6b)

Yield $89 \%$, m.p. $200^{\circ} \mathrm{C}-202^{\circ} \mathrm{C}$, IR $(\mathrm{KBr}) v\left(\mathrm{~cm}^{-1}\right)$ : 3360, 3290 and $3163(\mathrm{NH}), 1610(\mathrm{C}=\mathrm{S})$. MS (EI) $\mathrm{m} / \mathrm{z}$ : $297\left(\mathrm{M}^{+}, 60.5 \%\right) .{ }^{1} \mathrm{H}$ NMR (DMSO- $\left.d_{6}\right)(500 \mathrm{MHz}) \delta$ (ppm): 2.34 (s, $\left.3 \mathrm{H}, \mathrm{CH}_{3}\right), 2.52\left(\mathrm{~s}, 3 \mathrm{H}, \mathrm{CH}_{3}\right), 6.7(\mathrm{~s}, 1 \mathrm{H}$, C5-H), 7.3 - 7.82 (m, 5 H, Ar-H), 8.5, 9.2 (s, 2 H, 2 NH, $\mathrm{D}_{2} \mathrm{O}$ exchangeable), 13.0 ( $\mathrm{s}, \mathrm{H}, \mathrm{NH}$, pyrazole, $\mathrm{D}_{2} \mathrm{O}$ exchangeable). Anal. Calcd for $\mathrm{C}_{15} \mathrm{H}_{15} \mathrm{~N}_{5} \mathrm{~S}$ (297.38): $\mathrm{C}$, 60.58; H, 5.08; N, 23.55; S, 10.78. Found: C, 60.84; H, $5.25 ; \mathrm{N}, 23.39 ; \mathrm{S}, 10.92$.

$N$-(4,6-Dimethyl-1H-pyrazolo[3,4-b]pyridin-3-yl)acetamide (7a)

A solution of 3-amino pyrazolopyridine $4(0.01 \mathrm{~mol})$ and acetic anhydride $(30 \mathrm{~mL})$ was heated under reflux for $4 \mathrm{~h}$ and then cooled. The solid product formed was filtered off and crystallized from ethanol to afford compound $7 \mathrm{a}$.

Yield $89 \%$, m.p. $290^{\circ} \mathrm{C}-292^{\circ} \mathrm{C}$, IR $(\mathrm{KBr}) v\left(\mathrm{~cm}^{-1}\right)$ : $3145(\mathrm{NH}), 1680(\mathrm{C}=\mathrm{O})$. MS (EI) $\mathrm{m} / z: 204\left(\mathrm{M}^{+}, 80.5 \%\right)$. ${ }^{1} \mathrm{H}$ NMR (DMSO- $\left.d_{6}\right)(500 \mathrm{MHz}) \delta(\mathrm{ppm}): 2.02(\mathrm{~s}, 3 \mathrm{H}$, $\left.\mathrm{CH}_{3}\right), 2.34\left(\mathrm{~s}, 3 \mathrm{H}, \mathrm{CH}_{3}\right), 2.61\left(\mathrm{~s}, 3 \mathrm{H}, \mathrm{CH}_{3}\right), 6.8(\mathrm{~s}, 1 \mathrm{H}$, C5-H), 8.2 (s, $1 \mathrm{H}, \mathrm{NH}, \mathrm{D}_{2} \mathrm{O}$ exchangeable), 13.0 (s, $\mathrm{H}$, NH, pyrazole, $\mathrm{D}_{2} \mathrm{O}$ exchangeable). Anal. Calcd for $\mathrm{C}_{10} \mathrm{H}_{12} \mathrm{~N}_{4} \mathrm{O}$ (204.23): C, 58.81; H, 5.92; N, 27.43; O, 7.83. Found: C, 58.59; H, 5.65; N, 27.67; O, 7.53.

$\mathrm{N}$-(4,6-Dimethyl-1H-pyrazolo[3,4-b]pyridin-3-yl) benzamide (7b)

To a stirred iced solution of 3-amino pyrazolopyridine $4(0.01 \mathrm{~mol})$ in $\mathrm{CH}_{2} \mathrm{Cl}_{2}(8 \mathrm{~mL})$ containing few drops (5 $\mathrm{mL})$ of triethylamine benzoyl chloride $(0.01 \mathrm{~mol})$ was added drop wise and stirring continous for $1 \mathrm{~h}$ at r.t.. The 
solid product formed was filtered off and re-crystallized from ethanol to afford compound $7 \mathrm{~b}$.

Yield $83 \%$, m.p. $243^{\circ} \mathrm{C}-245^{\circ} \mathrm{C}$, IR $(\mathrm{KBr}) v\left(\mathrm{~cm}^{-1}\right)$ : $3200(\mathrm{NH}), 1660(\mathrm{C}=\mathrm{O})$. MS (EI) $m / z: 266\left(\mathrm{M}^{+}, 75 \%\right)$. ${ }^{1} \mathrm{H}$ NMR (DMSO- $\left.d_{6}\right)(500 \mathrm{MHz}) \delta$ (ppm): $2.4(\mathrm{~s}, 3 \mathrm{H}$, $\left.\mathrm{CH}_{3}\right), 2.7\left(\mathrm{~s}, 3 \mathrm{H}, \mathrm{CH}_{3}\right), 6.8(\mathrm{~s}, 1 \mathrm{H}, \mathrm{C} 5-\mathrm{H}), 7.4-7.7(\mathrm{~m}$, $5 \mathrm{H}, \mathrm{Ar}-\mathrm{H}), 8.1$ (s, $1 \mathrm{H}, \mathrm{NH}, \mathrm{D}_{2} \mathrm{O}$ exchangeable), 13.0 (s, $\mathrm{H}, \mathrm{NH}$, pyrazole, $\mathrm{D}_{2} \mathrm{O}$ exchangeable). Anal. Calcd for $\mathrm{C}_{15} \mathrm{H}_{14} \mathrm{~N}_{4} \mathrm{O}$ (266.3): C, 67.65; H, 5.30; N, 21.04; O, 6.01. Found: C, 67.39; H, 5.12; N, 21.29; O, 6.32 .

General procedure for the synthesis of compounds (7c-h)

Oxalyl chloride $(0.01 \mathrm{~mol})$ and a drop of DMF were added to a stirring solution of appropiate substituted carboxylic acid $(0.01 \mathrm{~mol})$, namely: 2-chlorobenzoic acid, 2-bromobenzoic acid, 2-methoxybenzoic acid, 2fouric acid, propionic acid and cinnamic acid in dry $\mathrm{CH}_{2} \mathrm{Cl}_{2}(8 \mathrm{~mL})$. The reaction mixture was allowed to stir at room temperature for $12 \mathrm{~h}$, and then 3-aminopyrazolopyridine $4(0.01 \mathrm{~mol})$ was added and the reaction mixture was continued to stir at room temperature for further $3 \mathrm{~h}$. Excess of $\mathrm{CH}_{2} \mathrm{Cl}_{2}$ was removed under reduced pressure. The residue was purified by shaking with diluted $\mathrm{HCl}$ in separating funnel, separate the aqueous layer and then dried with $\mathrm{MgSO}_{4}$ to afford $7 \mathrm{c}-\mathrm{h}$.

2-Chloro- $N$-(4,6-dimethyl-1H-pyrazolo[3,4-b]pyridin3-yl)benzamide (7c)

Yield $61 \%$, m.p. $138^{\circ} \mathrm{C}-140^{\circ} \mathrm{C}$, IR $(\mathrm{KBr}) v\left(\mathrm{~cm}^{-1}\right)$ : $3325(\mathrm{NH}), 1685(\mathrm{C}=\mathrm{O})$. MS (EI) $m / z: 300\left(\mathrm{M}^{+},{ }^{35} \mathrm{Cl}\right.$, $69.5 \%), 302\left(\mathrm{M}^{+}+2,{ }^{37} \mathrm{Cl}, 23.2 \%\right) .{ }^{1} \mathrm{H}$ NMR (DMSO- $d_{6}$ ) $(500 \mathrm{MHz}) \delta(\mathrm{ppm}): 2.29\left(\mathrm{~s}, 3 \mathrm{H}, \mathrm{CH}_{3}\right), 2.52(\mathrm{~s}, 3 \mathrm{H}$, $\mathrm{CH}_{3}$ ), 6.8 (s, $\left.1 \mathrm{H}, \mathrm{C} 5-\mathrm{H}\right), 7.4$ - 7.75 (m, $\left.4 \mathrm{H}, \mathrm{Ar}-\mathrm{H}\right), 7.9$ (s, $1 \mathrm{H}, \mathrm{NH}, \mathrm{D}_{2} \mathrm{O}$ exchangeable), $13.0(\mathrm{~s}, \mathrm{H}, \mathrm{NH}$, pyrazole, $\mathrm{D}_{2} \mathrm{O}$ exchangeable). Anal. Calcd for $\mathrm{C}_{15} \mathrm{H}_{13} \mathrm{ClN}_{4} \mathrm{O}$ (300.7): C, 59.91; H, 4.36; Cl, 11.79; N, 18.63; O, 5.32. Found: C, 59.63; H, 4.58; Cl, 11.92; N, 18.82; O, 5.64.

2-Bromo- $\mathrm{N}$-(4,6-dimethyl-1H-pyrazolo[3,4-b]pyridin3-yl)benzamide (7d)

Yield $69 \%$, m.p. $150^{\circ} \mathrm{C}-152^{\circ} \mathrm{C}$, IR $(\mathrm{KBr}) v\left(\mathrm{~cm}^{-1}\right)$ : $3330(\mathrm{NH}), 1670(\mathrm{C}=\mathrm{O})$. MS (EI) $m / z: 344\left(\mathrm{M}^{+}, 70 \%\right)$, $346\left(\mathrm{M}^{+}+1,69 \%\right) .{ }^{1} \mathrm{H}$ NMR (DMSO- $\left.d_{6}\right)(500 \mathrm{MHz}) \delta$ (ppm): 2.32 (s, $\left.3 \mathrm{H}, \mathrm{CH}_{3}\right), 2.60$ (s, $\left.3 \mathrm{H}, \mathrm{CH}_{3}\right), 6.9(\mathrm{~s}, 1 \mathrm{H}$, C5-H), 7.1 - 7.4 (m, $4 \mathrm{H}, \mathrm{Ar}-\mathrm{H}), 8.1\left(\mathrm{~s}, 1 \mathrm{H}, \mathrm{NH}, \mathrm{D}_{2} \mathrm{O}\right.$ exchangeable), 13.0 (s, H, NH, pyrazole, $\mathrm{D}_{2} \mathrm{O}$ exchangeable). Anal. Calcd for $\mathrm{C}_{15} \mathrm{H}_{13} \mathrm{BrN}_{4} \mathrm{O}$ (345.19): C, 52.19; $\mathrm{H}, 3.80 ; \mathrm{Br}, 23.15 ; \mathrm{N}, 16.23 ; \mathrm{O}, 4.63$ Found: C, 52.42; H, $3.53 ; \mathrm{Br}, 23.39 ; \mathrm{N}, 16.58 ; \mathrm{O}, 4.82$

2-Methoxy- $N$-(4,6-dimethyl-1H-pyrazolo[3,4-b]pyridin3-yl)benzamide (7e)

Yield $71 \%$, m.p. $118^{\circ} \mathrm{C}-120^{\circ} \mathrm{C}$, IR $(\mathrm{KBr}) v\left(\mathrm{~cm}^{-1}\right)$ : $3370(\mathrm{NH}), 1640(\mathrm{C}=\mathrm{O}), 1270$ (C-O). MS (EI) $m / z: 296$ $\left(\mathrm{M}^{+}, 65 \%\right) .{ }^{1} \mathrm{H}$ NMR (DMSO- $\left.d_{6}\right)(500 \mathrm{MHz}) \delta(\mathrm{ppm})$ : $2.32\left(\mathrm{~s}, 3 \mathrm{H}, \mathrm{CH}_{3}\right), 2.60\left(\mathrm{~s}, 3 \mathrm{H}, \mathrm{CH}_{3}\right), 3.7(\mathrm{~s}, 3 \mathrm{H}$, O- $\left.\mathrm{CH}_{3}\right), 6.8$ (s, $\left.1 \mathrm{H}, \mathrm{C} 5-\mathrm{H}\right), 7.1-7.4$ (m, $\left.4 \mathrm{H}, \mathrm{Ar}-\mathrm{H}\right), 8.5$ (s, $1 \mathrm{H}, \mathrm{NH}, \mathrm{D}_{2} \mathrm{O}$ exchangeable), 13.0 (s, H, NH, pyrazole, $\mathrm{D}_{2} \mathrm{O}$ exchangeable). Anal. Calcd for $\mathrm{C}_{16} \mathrm{H}_{16} \mathrm{~N}_{4} \mathrm{O}_{2}$ (296.32): C, 64.85; H, 5.44; N, 18.91; O, 10.80. Found: C, 64.59; H, 5.21; N, 18.71; O, 10.62 .

$\mathrm{N}$-(4,6-Dimethyl-1 $\mathrm{H}$-pyrazolo[3,4-b]pyridin-3-yl) furan-2-carboxamide (7f)

Yield $65 \%$, m.p. $130^{\circ} \mathrm{C}-132^{\circ} \mathrm{C}$, IR $(\mathrm{KBr}) v\left(\mathrm{~cm}^{-1}\right)$ : $3400(\mathrm{NH}), 1650(\mathrm{C}=\mathrm{O})$. MS (EI) $m / z: 256\left(\mathrm{M}^{+}, 85 \%\right)$. ${ }^{1} \mathrm{H}$ NMR (DMSO- $\left.d_{6}\right)(500 \mathrm{MHz}) \delta(\mathrm{ppm}): 2.40(\mathrm{~s}, 3 \mathrm{H}$, $\left.\mathrm{CH}_{3}\right), 2.72\left(\mathrm{~s}, 3 \mathrm{H}, \mathrm{CH}_{3}\right), 6.8(\mathrm{~s}, 1 \mathrm{H}, \mathrm{C} 5-\mathrm{H}), 7.4$ - $7.6(\mathrm{~m}$, $3 \mathrm{H}, \mathrm{Ar}-\mathrm{H}), 8.3$ (s, $1 \mathrm{H}, \mathrm{NH}, \mathrm{D}_{2} \mathrm{O}$ exchangeable), 13.0 (s, $\mathrm{H}, \mathrm{NH}$, pyrazole, $\mathrm{D}_{2} \mathrm{O}$ exchangeable). Anal. Calcd for $\mathrm{C}_{13} \mathrm{H}_{12} \mathrm{~N}_{4} \mathrm{O}_{2}$ (256.26): $\mathrm{C}, 60.93 ; \mathrm{H}, 4.72 ; \mathrm{N}, 21.86 ; \mathrm{O}$, 12.49. Found: C, 60.68; H, 4.49; N, 21.52; O, 12.13 .

(E)- $N$-(4,6-Dimethyl-1H-pyrazolo[3,4-b]pyridin-3yl)cinnamamide (7g)

Yield $66 \%$, m.p. $110^{\circ} \mathrm{C}-112^{\circ} \mathrm{C}$, IR $(\mathrm{KBr}) v\left(\mathrm{~cm}^{-1}\right)$ : $3260(\mathrm{NH}), 1680(\mathrm{C}=\mathrm{O}), 1580(\mathrm{C}=\mathrm{C})$. MS (EI) $\mathrm{m} / z: 292$ $\left(\mathrm{M}^{+}, 55 \%\right) .{ }^{1} \mathrm{H}$ NMR (DMSO- $\left.d_{6}\right)(500 \mathrm{MHz}) \delta(\mathrm{ppm})$ : $2.20\left(\mathrm{~s}, 3 \mathrm{H}, \mathrm{CH}_{3}\right), 2.51\left(\mathrm{~s}, 3 \mathrm{H}, \mathrm{CH}_{3}\right), 6.8(\mathrm{~s}, 1 \mathrm{H}, \mathrm{C} 5-\mathrm{H})$, 7.3 - $7.6(\mathrm{~m}, 5 \mathrm{H}, \mathrm{Ar}-\mathrm{H}), 8.2\left(\mathrm{~s}, 1 \mathrm{H}, \mathrm{NH}, \mathrm{D}_{2} \mathrm{O}\right.$ exchangeable), 8.3 (d, $1 \mathrm{H}, \mathrm{CH}), 8.6$ (d, $1 \mathrm{H}, \mathrm{CH}), 13.0$ (s, H, NH, pyrazole, $\mathrm{D}_{2} \mathrm{O}$ exchangeable). Anal. Calcd for $\mathrm{C}_{17} \mathrm{H}_{16} \mathrm{~N}_{4} \mathrm{O}$ (292.34): C, 69.85; H, 5.52; N, 19.17; O, 5.47. Found: C, 69.64; H, 5.21; N, 19.42; O, 5.21.

$\mathrm{N}$-(4,6-Dimethyl-1H-pyrazolo[3,4-b]pyridin-3-yl)-3phenylpropanamide (7h)

Yield $64 \%$, m.p. $128^{\circ} \mathrm{C}-130^{\circ} \mathrm{C}$, IR $(\mathrm{KBr}) v\left(\mathrm{~cm}^{-1}\right)$ : $3275(\mathrm{NH}), 1690(\mathrm{C}=\mathrm{O})$. MS (EI) $\mathrm{m} / z: 296\left(\mathrm{M}^{+}, 56 \%\right)$, $297\left(\mathrm{M}^{+}+1,55 \%\right) .{ }^{1} \mathrm{H}$ NMR (DMSO- $\left.d_{6}\right)(500 \mathrm{MHz}) \delta$ (ppm): 2.35 (s, $3 \mathrm{H}, \mathrm{CH}_{3}$ ), 2.4 (q, $\left.2 \mathrm{H}, \mathrm{CH} 2\right), 2.55$ (s, $3 \mathrm{H}$, CH3), 6.9 (s, $1 \mathrm{H}, \mathrm{C} 5-\mathrm{H}), 7.8$ (t, $\left.2 \mathrm{H}, \mathrm{CH}_{2}\right), 8.0$ (t, $2 \mathrm{H}$, $\left.\mathrm{CH}_{2}\right), 8.9$ (s, $1 \mathrm{H}, \mathrm{NH}, \mathrm{D}_{2} \mathrm{O}$ exchangeable), 13.0 (s, H, NH, pyrazole, $\mathrm{D}_{2} \mathrm{O}$ exchangeable). Anal. Calcd for $\mathrm{C}_{11} \mathrm{H}_{13^{-}}$ $\mathrm{BrN}_{4} \mathrm{O}$ (297.15): C, 44.46; H, 4.41; $\mathrm{Br}, 26.89 ; \mathrm{N}, 18.85$; O, 5.38. Found: C, 44.69; H, 4.71; Br, 26.63; N, 18.71; O, 5.52 .

General procedure for the synthesis of compounds (8a-b)

A mixture of 3-amino pyrazolopyridine $4(0.01 \mathrm{~mol})$ and appropiate active methylene reagents, namely: acetylacetone, ethyl acetoacetate ( 0.01 mole of each) in DMF $(30 \mathrm{~mL})$, containing few drops of piperidine was refluxed the $3 \mathrm{~h}$. After cooling, the solid product formed was collected by filtration and re-crystallized from $\mathrm{DMF} / \mathrm{EtOH}$ (1:3) to afford 8a-b.

2,4,8,10-Trimethylpyrido[2',3':3,4]pyrazolo[1,5-a]p yrimidine (8a)

Yield $82 \%$, m.p. $190^{\circ} \mathrm{C}-192^{\circ} \mathrm{C}$, MS (EI): $\mathrm{m} / z(\%) 226$ $\left(\mathrm{M}^{+}, 75 \%\right) .{ }^{1} \mathrm{H}$ NMR (DMSO- $\left.d_{6}\right)(500 \mathrm{MHz}) \delta(\mathrm{ppm})$ : $2.16\left(\mathrm{~s}, 3 \mathrm{H}, \mathrm{CH}_{3}\right), 2.25\left(\mathrm{~s}, 3 \mathrm{H}, \mathrm{CH}_{3}\right), 2.37\left(\mathrm{~s}, 3 \mathrm{H}, \mathrm{CH}_{3}\right)$, $2.54\left(\mathrm{~s}, 3 \mathrm{H}, \mathrm{CH}_{3}\right), 6.7(\mathrm{~s}, 1 \mathrm{H}, \mathrm{C} 9-\mathrm{H}), 7.82(\mathrm{~s}, 1 \mathrm{H}$, C3-H). Anal. Calcd for $\mathrm{C}_{13} \mathrm{H}_{14} \mathrm{~N}_{4}$ (226.28): C, 69.00; H, 6.24; N, 24.76. Found: C, 69.26; H, 6.01; N, 24.53. 


\section{4-Hydroxy-2,8,10-trimethylpyrido[2',3':3,4]pyrazolo [1,5-a]pyrimidine (8b)}

Yield $85 \%, \mathrm{mp} 290^{\circ} \mathrm{C}-292^{\circ} \mathrm{C}, \mathrm{IR}(\mathrm{KBr}) v\left(\mathrm{~cm}^{-1}\right)$ : $3340.45(\mathrm{OH})$. MS (EI) $\mathrm{m} / z: 228\left(\mathrm{M}^{+}, 67 \%\right) .{ }^{1} \mathrm{H}$ NMR $\left(\mathrm{DMSO}-d_{6}\right)(500 \mathrm{MHz}) \delta(\mathrm{ppm}): 2.24\left(\mathrm{~s}, 3 \mathrm{H}, \mathrm{CH}_{3}\right), 2.35$ (s, $\left.3 \mathrm{H}, \mathrm{CH}_{3}\right), 2.46\left(\mathrm{~s}, 3 \mathrm{H}, \mathrm{CH}_{3}\right), 5.82\left(\mathrm{~s}, \mathrm{H}, \mathrm{OH}, \mathrm{D}_{2} \mathrm{O}\right.$ exchangeable), 6.7 (s, $1 \mathrm{H}, \mathrm{C} 9-\mathrm{H}), 7.62(\mathrm{~s}, 1 \mathrm{H}, \mathrm{C} 3-\mathrm{H})$. Anal. Calcd for $\mathrm{C}_{12} \mathrm{H}_{12} \mathrm{~N}_{4} \mathrm{O}$ (228.25): C, 63.15; H, 5.30; N, 24.55; O, 7.01. Found: C, 63.43; H, 5.58; N, 24.73; O, 7.29 .

General procedure for the synthesis of compounds (10a-b)

To an ice-cooled solution of the 3-amino pyrazolopyridine $4(0.01 \mathrm{~mol})$ in $\mathrm{AcOH}(20 \mathrm{~mL})$ and conc. $\mathrm{HCl}(3$ $\mathrm{mL})$ a cold solution of sodium nitrite $(0.23 \mathrm{~g}$ in $5 \mathrm{~mL}$ of water) was added dropwise. The solution was stirred at room temperature for $3 \mathrm{~h}$ at $0^{\circ} \mathrm{C}-5^{\circ} \mathrm{C}$, and then treated with a solution of acetylacetone or ethyl cyanoacetate $(0.01 \mathrm{~mol})$ in the presence of sodiumacetate $(1 \mathrm{~g})$ in ethanol $(50 \mathrm{~mL})$. The reaction mixture was stirred in an ice-cold bath for $1 \mathrm{~h}$. The solid product obtained was filtered off, washed with water, and crystallized from ethanol to afford 10a-b.

\section{4-Acetyl-3,8,10-trimethylpyrido[2',3':3,4]pyrazolo} [5,1-c]-1,2,4-triazine (10a)

Yield $62 \%$, m.p. $240^{\circ} \mathrm{C}-242^{\circ} \mathrm{C}$, IR $(\mathrm{KBr}) v\left(\mathrm{~cm}^{-1}\right)$ : $1760(\mathrm{C}=\mathrm{O})$. MS (EI) $m / z: 256\left(\mathrm{M}^{+}, 68 \%\right) .{ }^{1} \mathrm{H}$ NMR $\left(\mathrm{DMSO}^{-} d_{6}\right)(500 \mathrm{MHz}) \delta(\mathrm{ppm}): 2.12\left(\mathrm{~s}, 3 \mathrm{H}, \mathrm{CH}_{3}\right), 2.32$ (s, $\left.3 \mathrm{H}, \mathrm{CH}_{3}\right), 2.75\left(\mathrm{~s}, 3 \mathrm{H}, \mathrm{CH}_{3}\right), 2.91\left(\mathrm{~s}, 3 \mathrm{H}, \mathrm{CH}_{3}\right), 6.7$ (s, $1 \mathrm{H}, \mathrm{C} 9-\mathrm{H}$ ). Anal. Calcd for $\mathrm{C}_{13} \mathrm{H}_{13} \mathrm{~N}_{5} \mathrm{O}$ (255.28): C, 61.17; H, 5.13; N, 27.43; O, 6.27. Found: C, 61.32; H, $5.39 ; \mathrm{N}, 27.75 ; \mathrm{O}, 6.51$.

Ethyl 3-amino-8,10-dimethylpyrido[2',3':3,4]pyrazolo [5,1-c]-1,2,4-triazine-4-carboxylate (10b)

Yield $74 \%$, m.p. $160^{\circ} \mathrm{C}-162^{\circ} \mathrm{C}$, IR $(\mathrm{KBr}) v\left(\mathrm{~cm}^{-1}\right)$ : 3348, $3250\left(\mathrm{NH}_{2}\right), 1711(\mathrm{C}=\mathrm{O}), 1260(\mathrm{C}-\mathrm{O}) . \mathrm{MS}(\mathrm{EI})$ $m / z: 286\left(\mathrm{M}^{+}, 74.5 \%\right) .{ }^{1} \mathrm{H}$ NMR (DMSO- $\left.d_{6}\right)(500 \mathrm{MHz})$ $\delta(\mathrm{ppm}): 1.5\left(\mathrm{t}, 3 \mathrm{H}, \mathrm{CH}_{2}-\mathrm{CH}_{3}\right), 2.35\left(\mathrm{~s}, 3 \mathrm{H}, \mathrm{CH}_{3}\right), 2.54$ (s, $\left.3 \mathrm{H}, \mathrm{CH}_{3}\right), 4.2\left(\mathrm{q}, 2 \mathrm{H}, \mathrm{CH}_{2}-\mathrm{CH}_{3}\right), 5.4\left(\mathrm{~s}, 2 \mathrm{H}, \mathrm{NH}_{2}\right.$, $\mathrm{D}_{2} \mathrm{O}$ exchangeable), 6.7 (s, $\left.1 \mathrm{H}, \mathrm{C} 9-\mathrm{H}\right)$. Anal. Calcd for $\mathrm{C}_{13} \mathrm{H}_{14} \mathrm{~N}_{6} \mathrm{O}_{2}$ (286.29): C, 54.54; H, 4.93; N, 29.35; O, 11.18. Found: C, 54.74; H, 4.75; N, 29.64; O, 11.31 .

\section{REFERENCES}

[1] A. Park, "In 40 Years of Cancer Research, How Far Have We Come?" Time Heatland, 2011. http://healthland.time.com/2011/09/21/cancer-researchs-4 0th-anniversary-how-far-have-we-come/\#more-43198

[2] G. Morgan, R. Ward and M. Barton, "The Contribution of Cytotoxic Chemotherapy to 5-Year Survival in Adult Malignancies," Journal of Clinical Oncology, Vol. 16, No. 8, 2004, pp. 549-560. doi:10.1016/j.clon.2004.06.007

[3] F. R. Lichtenberg, "Contribution of Pharmaceutical Innovation to Longevity Growth in Germany and France,"
Pharmacoeconomics, Vol. 30, No. 3, 2012, pp. 197-211. doi:10.2165/11587150-000000000-00000

[4] R. Li and J. A. Stafford, "Kinase Inhibitor Drugs," 1st Edition, John Wiley \& Sons, Hoboken, 2009. doi:10.1002/9780470524961

[5] D. R. Robinson, Y. Wu and S. Lin, "The Protein Tyrosine Kinase Family of the Human Genome," Oncogene, Vol. 19, No. 49, 2000, pp. 5548-5557. doi:10.1038/sj.onc.1203957

[6] J. Zhang, P. L. Yang and N. S. Gray, "Targeting Cancer with Small Molecule Kinase Inhibitors," Nature Reviews Cancer, Vol. 9, No. 1, 2009, pp. 28-39. doi: $10.1038 / \mathrm{nrc} 2559$

[7] B. J. Druker, S. Tamura, E. Buchdunger, S. Ohno, G. M. Segal, S. Fanning, J. Zimmermann and N. B. Lydon, "Effects of a Selective Inhibitor of the Abl Tyrosine Kinase on the Growth of Bcr-Abl Positive Cells," Nature Medicine, Vol. 2, No. 5, 1996, pp. 561-566. doi:10.1038/nm0596-561

[8] R. Capdeville, E. Buchdunger, J. Zimmermann and A. Matter, "Glivec (STI571, Imatinib), a Rationally Developed, Targeted Anticancer Drug," Nature Reviews Drug Discovery, Vol. 1, No. 7, 2002, pp. 493-502. doi:10.1038/nrd839

[9] M. C. Heinrich, D. J. Griffith, B. J. Druker, C. L. Wait, K. A. Ott and A. J. Zigler, "Inhibition of c-Kit Receptor Tyrosine Kinase Activity by STI 571, a Selective Tyrosine Kinase Inhibitor," Blood, Vol. 96, No. 3, 2000, pp. 925 932.

[10] C. M. Christensen, "The Innovator's Dilemma: When New Technologies Cause Great Firms to Fail," Harvard Business School Press, Cambridge, 1997.

[11] J. P. Overington, B. Al-Lazikani and A. L. Hopkins, "How Many Drug Targets Are There?" Nature Reviews Drug Discovery, Vol. 5, No. 12, 2006, pp. 993-996. doi:10.1038/nrd2199

[12] S. Frantz, "Drug Discovery: Playing Dirty," Nature, Vol. 437, No. 7061, 2005, pp. 942-943. doi: $10.1038 / 437942 \mathrm{a}$

[13] A. L. Hopkins, "Drug Discovery: Predicting Promiscuity," Nature, Vol. 462, No. 7270, 2009, pp. 167-168. doi:10.1038/462167a

[14] J. Vesely, L. Havlicek, M. Strnad, J. J. Blow, A. DonellaDeana, L. Pinna, D. S. Letham, J. Kato, L. Detivaud and S. LeClerc, "Inhibition of Cyclin-Dependent Kinases by Purine Analogues," European Journal of Biochemistry, Vol. 224, No. 2, 1994, pp. 771-786. doi:10.1111/j.1432-1033.1994.00771.x

[15] L. Meijer and E. Raymond, "Roscovitine and Other Purines as Kinase Inhibitors, from Starfish Oocytes to Clinical Trials," Accounts of Chemical Research, Vol. 36, No. 6, 2003, pp. 417-425. doi:10.1021/ar0201198

[16] R. Jorda, L. Havlíček, I. W. McNae, M. D. Walkinshaw, J. Voller, S A. turc, J. Navratilova, M. Kuzma, M. Mistrik, J. Bartek, M. Strnad and V. Krystof, "Pyrazolo[4,3-d]pyrimidine Bioisostere of Roscovitine: Evaluation of a Novel Selective Inhibitor of Cyclin-Dependent Kinases with Antiproliferative Activity," Journal of Medicinal 
Chemistry, Vol. 54, No. 8, 2011, pp. 2980-2993. doi:10.1021/jm200064p

[17] M. F. Braña, M. Cacho, M. L. Garci'a, E. P. Mayoral, B. Lo'pez, B. de Pascual-Teresa, A. Ramos, N. Acero, F. Llinares, D. Muñoz-Mingarro, O. Lozach and L. Meijer, "Pyrazolo[3,4-c]pyridazines as Novel and Selective Inhibitors of Cyclin-Dependent Kinases," Journal of Medicinal Chemistry, Vol. 48, No. 22, 2005, pp. 6843-6854. doi:10.1021/jm058013g

[18] F. A. Yassin, "Synthesis, Reactions and Biological Activity of 2-Substituted 3-Cyano-4,6-Dimethylpyridine Derivatives," Chemistry of Heterocyclic Compounds, Vol. 45, No. 1, 2009, pp. 35-41. doi:10.1007/s10593-009-0222-x

[19] A. M. Hussein, E. A. Ishak, A. A. Atalla, S. Abdel Hafiz and M. H. Elnagdi, "Phenylacetone as Building Blocks in Heterocyclic Synthesis: Synthesis of PolyfunctionallySubstituted Pyridines, and Fused Pyridines," Phosphorus, Sulfur, and Silicon and the Related Elements, Vol. 182, No. 12, 2007, pp. 2897-2917. doi: $10.1080 / 10426500701542858$
[20] U. Schulze-Gahmen, H. L. De Bondt and S. Kim, "HighResolution Crystal Structures of Human Cyclin-Dependent Kinase 2 with and without ATP: Bound Waters and Natural Ligand as Guides for Inhibitor Design," Journal of Medicinal Chemistry, Vol. 39, No. 23, 1996, pp. 45404546. doi:10.1021/jm960402a

[21] C. E. Arris, F. T. Boyle, A. H. Calvert, N. J. Curtin, J. A. Endicott, E. F. Garman, A. E. Gibson, B. T. Golding, S. Grant, R. J. Griffin, P. Jewsbury, L. N. Johnson, A. M. Lawrie, D. R. Newell, M. E. Noble, E. A. Sausville, R. Schultz and $\mathrm{W}$. Yu, "Identification of Novel Purine and Pyrimidine Cyclin-Dependent Kinase Inhibitors with Distinct Molecular Interactions and Tumor Cell Growth Inhibition Profiles," Journal of Medicinal Chemistry, Vol. 43, No. 15, 2000, pp. 2797-2804. doi:10.1021/jm9906280

[22] P. Furet, "X-Ray Crystallographic Studies of CDK2, a Basis for Cyclin-Dependent Kinase Inhibitor Design in Anti-Cancer Drug Research," Current Medicinal Chemistry Anti-Cancer Agents, Vol. 3, No. 1, 2003, pp. 15-23. doi:10.2174/1568011033353515 